\title{
Evidence for benthic-pelagic food web coupling and carbon export from California margin bamboo coral archives
}

\author{
T. M. Hill ${ }^{1,2}$, C. R. Myrvold ${ }^{1}$, H. J. Spero ${ }^{1}$, and T. P. Guilderson ${ }^{3,4}$ \\ ${ }^{1}$ Department of Earth \& Planetary Sciences, University of California, Davis CA, USA \\ ${ }^{2}$ Bodega Marine Laboratory, University of California, Bodega Bay, CA, USA \\ ${ }^{3}$ Center for Accelerator Mass Spectrometry, Lawrence Livermore National Laboratory, Livermore CA, USA \\ ${ }^{4}$ Department of Ocean Sciences, University of California, Santa Cruz, CA, USA \\ Correspondence to: T. M. Hill (tmhill@ucdavis.edu)
}

Received: 20 January 2014 - Published in Biogeosciences Discuss.: 13 February 2014

Revised: 23 May 2014 - Accepted: 12 June 2014 - Published: 22 July 2014

\begin{abstract}
Deep-sea bamboo corals (order Gorgonacea, family Isididae) are known to record changes in water mass chemistry over decades to centuries. These corals are composed of a two-part skeleton of calcite internodes segmented by gorgonin organic nodes. We examine the spatial variability of bamboo coral organic node ${ }^{13} \mathrm{C} /{ }^{12} \mathrm{C}$ and ${ }^{15} \mathrm{~N} /{ }^{14} \mathrm{~N}$ from 13 bamboo coral specimens sampled along the California margin (37-32 $\mathrm{N}, 792-2136 \mathrm{~m}$ depth). Radiocarbon analyses of the organic nodes show the presence of the anthropogenic bomb spike, indicating the corals utilize a surface-derived food source (pre-bomb $\mathrm{D}^{14} \mathrm{C}$ values of $\sim-100 \%$, post-bomb values up to $82 \%$ ). Carbon and nitrogen isotope data from the organic nodes $\left(\delta^{13} \mathrm{C}=-15.9 \%\right.$ to $-19.2 \%$; $\delta^{15} \mathrm{~N}=13.8 \%$ o to $19.4 \%$ o) suggest selective feeding on surface-derived organic matter or zooplankton. A strong relationship between coral $\delta^{15} \mathrm{~N}$ and habitat depth indicates a potential archive of changing carbon export, with decreased $\delta^{15} \mathrm{~N}$ values reflecting reduced microbial degradation (increased carbon flux) at shallower depths. Using four multi-centennial-length coral records, we interpret long-term $\delta^{15} \mathrm{~N}$ stability in the California Current. Organic node $\delta^{13} \mathrm{C}$ values record differences in carbon isotope fractionation dictated by nearshore vs. offshore primary production. These findings imply strong coupling between primary production, pelagic food webs, and deep-sea benthic communities.
\end{abstract}

\section{Introduction}

Recent studies have shown that deep-sea corals (DSCs) are an important archive of geochemical information for reconstructing past ocean circulation and environmental variability (Smith et al., 2000; Adkins et al., 2003; Thresher et al., 2004; Robinson et al., 2005; Sherwood et al., 2005; Sherwood et al., 2009; Sherwood and Edinger, 2009). Bamboo corals (family Isididae) are gorgonian octocorals found in areas such as the Gulf of Alaska (Roark et al., 2005), south/southeast of Tasmania (Thresher et al., 2004), New Zealand (Noe and Dullo, 2006), and the California margin (Hill et al., 2011; LaVigne et al., 2011; Hill et al., 2012). These corals derive their name from a skeletal structure of calcite internodes segmented by gorgonin organic nodes, forming a bamboo-like structure (Fig. 1) (Roark et al., 2005; Hill et al., 2011; Noe and Dullo, 2006). Bamboo corals live up to 400 years (Thresher et al., 2004) and extend both their calcite skeleton and organic nodes in concentric rings, thereby producing temporally linked organic and inorganic material for geochemical analyses that record annual to subannual environmental information.

Calcite internode geochemistries $\left(\mathrm{D}^{14} \mathrm{C}, \delta^{18} \mathrm{O}, \delta^{13} \mathrm{C}\right)$ of bamboo corals indicate that the calcite skeleton is derived from dissolved inorganic carbon (DIC) in the surrounding intermediate waters (Roark et al., 2005; Hill et al., 2011). In contrast, radiocarbon $\left(\mathrm{D}^{14} \mathrm{C}\right)$ analyses of several different types of DSC, including bamboo corals, demonstrate that the organic skeletal material reflects a surface-derived signal (Roark et al., 2005; Griffin and Druffel, 1989; Sherwood et 


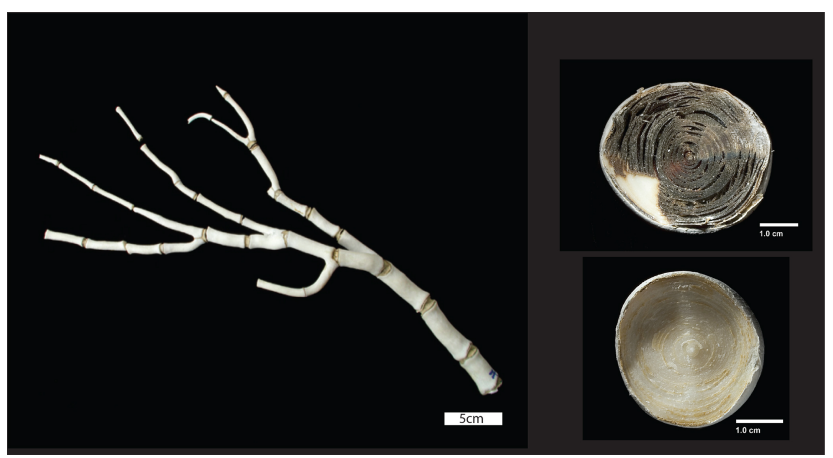

Figure 1. Left: photograph of bamboo coral specimen showing calcite internodes connected by gorgonin nodes. Right: cross-section view of gorgonin section (top) and calcite section (bottom), exhibiting evidence of growth in concentric rings. Photographs by M. Graziose.

al., 2009; Sherwood and Edinger, 2009). DSCs feed on sinking particulate organic matter (POM) or zooplankton (Griffin and Druffel, 1989; Sherwood et al., 2009; Sherwood et al., 2005). Thus, through proxy development and validation, bamboo corals may provide a unique opportunity to reconstruct past surface and deepwater processes from the same coral specimens.

This study examines $\delta^{13} \mathrm{C}, \delta^{15} \mathrm{~N}$, and $\mathrm{D}^{14} \mathrm{C}$ variability in 13 bamboo coral specimens sampled along the California margin from intermediate water depths (792-2136 m). In this region, the southward-flowing California Current dominates this system for most of the year, while the weaker northwardflowing Davidson Current becomes more prevalent during the winter months (Chelton et al., 1982; Largier et al., 1993). Strong northerly winds along the western North American coast allow for coastal upwelling on the California margin generally commencing during March and continuing until winter (Huyer, 1983; Strub et al., 1987; Largier et al., 1993). Previous investigations of bamboo corals from this region indicate that their calcite geochemistry is a proxy for temperature $\left(\delta^{18} \mathrm{O}, \delta^{13} \mathrm{C}\right)$ and refractory nutrient concentrations $(\mathrm{Ba} / \mathrm{Ca})$ of local intermediate waters, as well as an advected signal of productivity $(\mathrm{Sr} / \mathrm{Ca})$ from the North Pacific Gyre (Hill et al., 2011, 2012; LaVigne et al., 2011). The goals of this study were to utilize organic node geochemistry to (1) assess the use of the anthropogenic radiocarbon "bomb spike" as a potential chronological tool; (2) determine the primary food source of bamboo corals using isotopic tracers; and (3) evaluate the utility of organic node geochemistry in recording surface water processes.

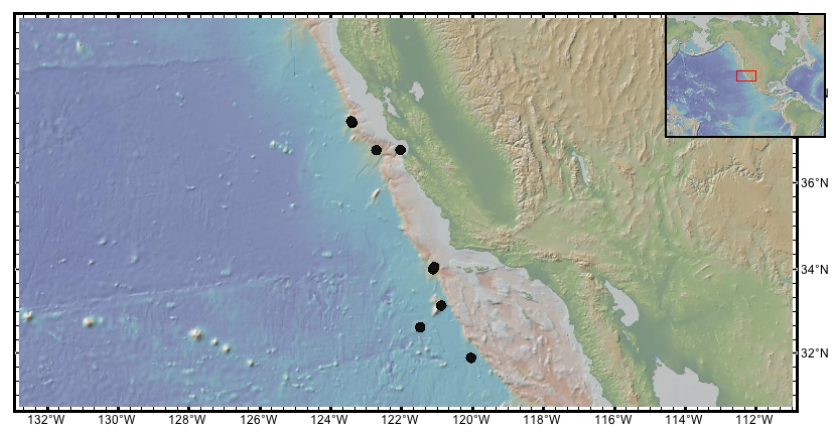

Figure 2. Bathymetric map of study area with coral sampling locations noted. Map generated using GeoMappApp.

\section{Materials and methods}

\subsection{Coral samples}

Specimens of bamboo corals utilized in this study were collected as part of two expeditions on the Monterey Bay Aquarium Research Institute (MBARI) vessel R/V Western Flyer utilizing the ROV Tiburon along the California margin, including six seamounts, and Monterey Canyon in 2004 and 2007 (Table 1, Fig. 2). These specimens were collected at depths ranging from 792 to $2136 \mathrm{~m}$ and at latitudes of $31.9-37.4^{\circ} \mathrm{N}$. Corals with no polyp material at the base of the skeleton, or complete absence of polyps, were noted as "dead"; live corals were characterized by the presence of polyp material extending across the entire specimen. For live specimens, the polyp material was removed from the coral skeleton post-collection and the corals were archived dry, at UC Davis Bodega Marine Laboratory.

Organic nodes from the basal section (that nearest the attachment to substrate) of the coral were selected for subsequent analyses. Separation of the organic nodes from the calcite internodes (Fig. 1) was accomplished by cutting the calcite above and below the node with a diamond saw and subsequent immersion of the node in $0.6 \mathrm{~N} \mathrm{HCl}$ to remove the remaining calcite interspersed throughout the node. Once the calcite was removed, the nodes were stored in deionized water prior to subsampling for isotopic analyses. Individual nodes were sampled at $\sim 1 \mathrm{~mm}$ intervals using forceps and scalpel under a stereomicroscope. These samples were then dried overnight at $90^{\circ} \mathrm{C}$ and stored in polyethylene vials at room temperature.

\subsection{Radiocarbon analyses}

Ten coral specimens were sampled radially for radiocarbon analyses, at $\sim 1 \mathrm{~mm}$ sample resolution. Radiocarbon analyses of the organic nodes were performed by the Center for Accelerator Mass Spectrometry (CAMS) at the Lawrence Livermore National Laboratory (LLNL). Samples were converted to $\mathrm{CO}_{2}$ and then reduced to graphite targets in the presence of iron catalyst. Results include a ${ }^{14} \mathrm{C}$-free 
Table 1. Coral samples utilized in this investigation. All corals were collected from seamounts on the California margin, with the exception of corals collected within the Monterey Canyon area.

\begin{tabular}{llrrrr}
\hline Sample ID & Location & Depth $(\mathrm{m})$ & Latitude & Longitude & Alive/dead \\
\hline T668 A13 & Little Joe & 2136 & 31.906 & -120.046 & Dead \\
T669 A1 & San Marcos & 2043 & 32.636 & -121.482 & Dead \\
T664 A2 & San Juan & 1954 & 33.149 & -120.887 & Live \\
T664 A1 & San Juan & 2055 & 33.151 & -120.882 & Dead \\
T670 A20 & Rodriguez & 1093 & 34.004 & -121.116 & Dead \\
T661 A9 & Rodriguez & 792 & 34.054 & -121.084 & Live \\
T1102 A3 & Davidson & 1647 & 36.742 & -122.717 & Live \\
T1104 A7 & Monterey Canyon & 870 & 36.744 & -122.037 & Live \\
T1104 A3 & Monterey Canyon & 917 & 36.744 & -122.037 & Dead \\
T1100 A4 & Pioneer & 1285 & 37.359 & -123.394 & Live \\
T1101 A13 & Pioneer & 1012 & 37.371 & -123.409 & Live \\
T1101 A12 & Pioneer & 1012 & 37.371 & -123.409 & Dead \\
T892 A8 & Pioneer & 1202 & 37.393 & -123.428 & Dead \\
\hline
\end{tabular}

background correction, and $\delta^{13} \mathrm{C}$ normalization. Results are reported as conventional (non-reservoir-corrected) radiocarbon age (per mil $(\%) \mathrm{D}^{14} \mathrm{C}$ ); data are thus $\delta^{13} \mathrm{C}$-normalized, but not age-corrected, as per international convention put forth in Stuiver and Polach, 1977).

\subsection{Isotopic analyses}

Ten coral specimens were sampled for organic node stable isotopic composition. Corals were sampled along a radial cross section at $1 \mathrm{~mm}$ resolution to a maximum distance of $20-35 \mathrm{~mm}$ for the larger corals. Both $\delta^{13} \mathrm{C}$ and $\delta^{15} \mathrm{~N}$ analyses of the organic nodes were performed by the Stable Isotope Facility at the University of California, Davis. Organic node samples were combusted at $1020^{\circ} \mathrm{C}$ and analyzed on a PDZ Europa ANCA-GSL elemental analyzer coupled to a PDZ Europa 20-20 isotope ratio mass spectrometer using helium as a carrier gas, with the resulting $\mathrm{N}_{2}$ and $\mathrm{CO}_{2}$ samples separated on a Carbosieve GC (gas chromatography) column prior to mass spectrometer analysis. Repeated laboratory standards $\left(\delta^{13} \mathrm{C}=-24.47 \pm 0.20 \%\right.$; $\delta^{15} \mathrm{~N}=1.40 \pm 0.21 \%$ o were utilized to determine and correct any offset or drift from certified reference materials. Stable isotope values are reported in standard permil notation, relative to $\delta^{13} \mathrm{C}$ and $\delta^{15} \mathrm{~N}$ reference standards (Vienna Pee Dee Belemnite and air, respectively).

\section{Results and discussion}

\subsection{Radiocarbon analyses and calculated extension rates}

Organic nodes from the coral specimens investigated here exhibit pre-anthropogenic $\mathrm{D}^{14} \mathrm{C}$ values of $-101 \pm 15 \%$ in the interior of the skeleton. Six of the coral specimens, primarily those that were collected alive, exhibit a range of enriched
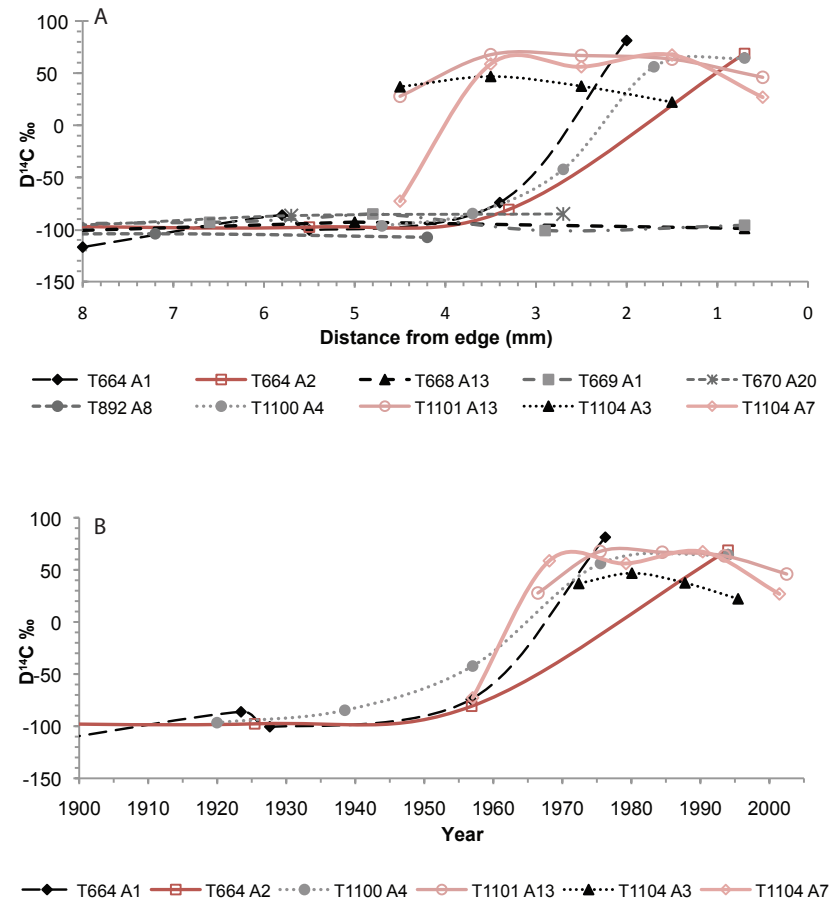

Figure 3. (A) Radiocarbon analyses on live (red symbols) and dead (black or grey symbols) coral specimens, plotted as distance from edge. (B) Radiocarbon analyses on corals with the "bomb spike" apparent, plotted versus age. Coral chronologies are based upon growth rates calculated in Table 3 .

and clearly post-bomb (post-1957) values near the outer edge of the skeleton $(0-5 \mathrm{~mm})$, with $\mathrm{D}^{14} \mathrm{C}$ ranging from +22 to $+68 \%$ (Table 2; Fig. 3). We note that all of these corals with enriched $\mathrm{D}^{14} \mathrm{C}$ were sampled within $250 \mathrm{~km}$ of the coastline, across a range of sampling depths (Table 1, Table 2). Interior samples exhibit typical (pre-bomb) $\mathrm{D}^{14} \mathrm{C}$ values of $-101 \pm 15 \%$. 
Table 2. Radiocarbon analyses on organic nodes presented in Fig. 3.

\begin{tabular}{|c|c|c|c|c|c|}
\hline ID & $\begin{array}{r}\text { Distance } \\
\text { from edge } \\
(\mathrm{mm})\end{array}$ & $\begin{array}{r}\mathrm{D}^{14} \mathrm{C} \\
(\% \circ)\end{array}$ & \pm & $\begin{array}{r}\text { Water } \\
\text { depth } \\
(\mathrm{m})\end{array}$ & $\begin{array}{r}\text { Distance } \\
\text { from } \\
\text { shore }(\mathrm{km})\end{array}$ \\
\hline \multirow[t]{3}{*}{ T668 A13 } & 0.7 & -99 & 4.8 & 2055 & 237 \\
\hline & 5 & -4.7 & & & \\
\hline & 10.2 & -106.6 & 4.3 & & \\
\hline \multirow[t]{5}{*}{ T669 A1 } & 0.7 & -95.9 & 3.4 & 1954 & 237 \\
\hline & 2.9 & -101 & 3.5 & & \\
\hline & 4.8 & -85.1 & 4 & & \\
\hline & 6.6 & -93.1 & 3.4 & & \\
\hline & 22.8 & -102.8 & 3.4 & & \\
\hline \multirow[t]{6}{*}{ T670 A20 } & 2.7 & -85.1 & 3.6 & 1012 & 82.09 \\
\hline & 5.7 & -86.7 & 3.2 & & \\
\hline & 8.7 & -96.3 & 3.4 & & \\
\hline & 11.7 & -81.3 & 3.4 & & \\
\hline & 14.7 & -83.6 & 3.4 & & \\
\hline & 17.7 & -83.1 & 3.4 & & \\
\hline \multirow[t]{3}{*}{ T892 A8 } & 4.2 & -107.5 & 4.9 & 1093 & 390 \\
\hline & 7.2 & -104.1 & 5.7 & & \\
\hline & 12.2 & -106.4 & 4.5 & & \\
\hline \multirow[t]{5}{*}{ T1100 A4 } & 0.7 & 64.5 & 3.8 & 1202 & 85 \\
\hline & 1.7 & 56.1 & 3.9 & & \\
\hline & 2.7 & -42.3 & 3.1 & & \\
\hline & 3.7 & -84.7 & 4.1 & & \\
\hline & 4.7 & -96.6 & 3.4 & & \\
\hline \multirow[t]{5}{*}{ T1101 A13 } & 0.5 & 46 & 4.6 & 917 & 20 \\
\hline & 1.5 & 63.4 & 4.3 & & \\
\hline & 2.5 & 66.9 & 3.7 & & \\
\hline & 3.5 & 67.7 & 6.4 & & \\
\hline & 4.5 & 27.8 & 4.9 & & \\
\hline \multirow[t]{4}{*}{ T1104 A3 } & 1.5 & 22.2 & 4.2 & 870 & 20 \\
\hline & 2.5 & 37.5 & 4.2 & & \\
\hline & 3.5 & 46.8 & 4.3 & & \\
\hline & 4.5 & 36.9 & 4.3 & & \\
\hline \multirow[t]{5}{*}{ T1104 A7 } & 0.5 & 26.9 & 4.7 & 870 & 20 \\
\hline & 1.5 & 67.4 & 4.3 & & \\
\hline & 2.5 & 56.1 & 4.4 & & \\
\hline & 3.5 & 58.7 & 4.4 & & \\
\hline & 4.5 & -72.8 & 3.8 & & \\
\hline \multirow[t]{5}{*}{ T664 A1 } & 2 & 81.3 & 4 & 2055 & 237 \\
\hline & 3.4 & -74.2 & 3.5 & & \\
\hline & 5.5 & -100.5 & 3.4 & & \\
\hline & 5.8 & -86.2 & 3.4 & & \\
\hline & 8 & -116.9 & 3.1 & & \\
\hline \multirow[t]{4}{*}{ T664 A2 } & 0.7 & 68.8 & 4.3 & 1954 & 237 \\
\hline & 3.3 & -80.8 & 4 & & \\
\hline & 5.5 & -97.7 & 3.8 & & \\
\hline & 9.1 & -96.3 & 3.6 & & \\
\hline
\end{tabular}

$\mathrm{D}^{14} \mathrm{C}$ data from all organic node samples from livecollected specimens exhibit a significant excursion near the outer $5 \mathrm{~mm}$ of the coral. Two of the dead specimens also exhibit this trend. The remaining bamboo corals collected dead exhibit relatively constant $\mathrm{D}^{14} \mathrm{C}$ values. The elevated $\mathrm{D}^{14} \mathrm{C}$ signal observed in six of the corals is consistent with increased ${ }^{14} \mathrm{C}$ in the atmosphere and surface waters due to atmospheric nuclear bomb testing during the 1950s and early 1960s (the bomb spike) (Nydal and Lovseth, 1983; Broecker et al., 1985). "Bomb radiocarbon" has been previously observed in surface waters, surface water organisms, and other DSC investigations (e.g., Broecker et al., 1985; Ebert and Southon, 2003; Roark et al., 2005; Sherwood et al., 2009; Benavides and Druffel, 1986; Rosenheim and Swart, 2007; Moore et al., 1997). We interpret the presence of the anthropogenic bomb spike in these bamboo corals as indicative of a surface-water food source influencing the organic node geochemistry (Fig. 3).

The presence of bomb radiocarbon $\left(\mathrm{D}^{14} \mathrm{C}\right.$ values of $\geq-85 \%$ for surface waters in this region) (Ingram and Southon, 1996) can be utilized as a chronologic marker (Roark et al., 2005; Sherwood et al., 2009). We note that, prior to the presence of bomb radiocarbon in our samples, radiocarbon values are mostly constant (Fig. 3). This observation is well known in the atmospheric ${ }^{14} \mathrm{C}$ record (so-called "radiocarbon plateaus"; Stuiver and Brazunias 1986; Reimer et al., 2013). We infer that the nearly constant values that we observe are associated with the plateau and relative insensitivity of radiocarbon in surface waters between the mid- to late 1600s and $\sim 1950 \mathrm{AD}$ (Stuiver 1965; Stuiver and Quay 1981; Reimer et al., 2013).

The timing of the surface ocean expression of the rise in bomb ${ }^{14} \mathrm{C}$ allows for a consistent relative age dating among these corals, given that the onset of ${ }^{14} \mathrm{C}$ increase in Northern Hemisphere surface waters is dated to $1957 \pm 2$ years (Manning et al., 1990; Kerr et al., 2005); we utilize this date for the onset of $\mathrm{D}^{14} \mathrm{C}$ increase in the corals. For two corals that do not extend back far enough to record the onset of the $\mathrm{D}^{14} \mathrm{C}$ increase, we utilize a tie point to the $\mathrm{D}^{14} \mathrm{C}$ maximum, with a date of 1980 as presented in Roark et al. (2005); we expect this date to be regionally coherent. These two tie points are utilized to calculate gorgonin $\mathrm{D}^{14} \mathrm{C}$-based extension rates (Fig. 3; Table 3). The relative stability of the $\mathrm{D}^{14} \mathrm{C}$ record after the initial (1957) increase is also consistent with surface water records, which exhibit a plateau or only slight decrease in $\mathrm{D}^{14} \mathrm{C}$ after the bomb spike (in contrast to the atmospheric record, which exhibits a clearer $\mathrm{D}^{14} \mathrm{C}$ decrease post-1980) (Tisnerat-Laborde et al., 2013; Roark et al., 2005; Ebert and Southon, 2003).

The calculated gorgonin radial extension rates (Table 3) are within the previously published calcite extension rates for bamboo corals in this region (Hill et al., 2011). The gorgonin extension rate from one coral (T664 A1) of $72 \mu \mathrm{m} \mathrm{yr}^{-1}$ (Table 3 ) is consistent with the ${ }^{14} \mathrm{C}$-based radial extension rate calculated for the calcite internode from the same coral (Hill et al., 2011). Calculated extension rates are assumed to reflect average rates for the lifetime of the coral; however, we acknowledge that the coral chronologies are the most robust between 1950 and 2000, near tie points in the post-bomb era. Specifically, at the tie point to the 1957 increase in $\mathrm{D}^{14} \mathrm{C}$, chronological error may be as small as \pm 2 years (the error on the atmospheric bomb carbon record) (Manning et al., 1990; Kerr et al., 2005). During the remainder of the record, the chronological accuracy relies on an assumption of constant 
Table 3. Calculated radial extension rates based upon $\mathrm{D}^{14} \mathrm{C}$ and correlation to bomb carbon.

\begin{tabular}{lllll}
\hline & $\begin{array}{l}\text { Onset of } \mathrm{D}^{14} \mathrm{C} \\
\text { increase 1957 } \\
\text { mm from edge }\end{array}$ & $\begin{array}{l}\text { Extension rate } \\
\mu \mathrm{yr}^{-1}\end{array}$ & $\begin{array}{l}\text { Peak of } \mathrm{D}^{14} \mathrm{C} \\
1980 \\
\mathrm{~mm} \text { from edge }\end{array}$ & $\begin{array}{l}\text { Extension rate } \\
\mu \mathrm{yr}^{-1}\end{array}$ \\
\hline T6ral ID & 3.4 & 72 & & \\
T664 A2 & 3.3 & 70 & & 93 \\
T1100 A4 & 2.7 & 54 & 2.5 & 93 \\
T1101 A13 & & & 2.5 & \\
T1104 A3 & & & & \\
T1104 A7 & 4.5 & 90 & & \\
\hline
\end{tabular}

average extension rates. Previous investigations on bamboo corals from the California margin have indicated that average calcite extension rates (from $\mathrm{D}^{14} \mathrm{C}$ and growth band measurements) can range as much as $\pm 52 \mu \mathrm{m} \mathrm{yr}^{-1}$ (Hill et al., 2011). With an average extension rate from the corals investigated here of $73 \mu \mathrm{m} \mathrm{yr}^{-1}$ (calculated from values in Table 3), this would imply an additional error of \pm 0.71 years associated with variation in coral growth rates over time. This source of error would be additive over time (increasing distance from the 1957 tie point). We acknowledge that this magnitude of error is consistent with the size of the drilled samples $(1 \mathrm{~mm})$, which would impose an "averaging" of $\sim 13$ years for each discrete sample (based upon a growth rate of $73 \mu \mathrm{m} \mathrm{yr}^{-1}$ ). The use of the $\mathrm{D}^{14} \mathrm{C}$ bomb spike as chronological tie points also assumes the rapid transport of POM/zooplankton to the deep sea, and thus little to no delay in the $\mathrm{D}^{14} \mathrm{C}$ signal reaching the DSCs via the food web. This assumption is supported by regional studies of carbon export as discussed below, which provide evidence that the corals are not feeding on degraded POM. We acknowledge that, if corals fed on more degraded POM (as observed in Sherwood et al., 2009), the radiocarbon tie points may require some "lag" from surface waters, which would lead to an underestimation of growth rates in Table 3.

We interpret that the lack of a bomb carbon signal in the dead corals may be due to the removal of the outer gorgonin material due to predation on living polyps by predators, or degradation following coral death. During collection dives, corals were observed being preyed upon by sea stars. The exposure of the organic nodes due to removal of polyps could potentially lead to biologic consumption or gorgonin and/or chemical degradation from the surrounding water. Such removal of node material could, under exceptional instances, introduce hiatuses that would influence the isotopic record, as discussed below. Dead corals may also simply reflect growth from prior to 1957 , and thus have no record of the atmospheric bomb spike.

\subsection{Isotopic analyses}

$\delta^{13} \mathrm{C}$ and $\delta^{15} \mathrm{~N}$ data are presented in Fig. 4. For specimens with more than 15 subsamples along a radial transect, we only present the first $15 \mathrm{~mm}$ in Fig. 4 to limit interpretation to recent skeletal precipitation. The total range of $\delta^{15} \mathrm{~N}$ values observed from these specimens was $13.8-19.4 \%$ o $(1 \sigma=$ $\pm 1.81 \%$ ). Variation within a single coral skeleton (intracolony) in $\delta^{15} \mathrm{~N}$ was $1-2 \%$. The total range in $\delta^{13} \mathrm{C}$ composition was -15.9 to $-19.2 \%$ o $(1 \sigma= \pm 0.70 \%$ ). Maximum intracolony variation in $\delta^{13} \mathrm{C}$ composition was $2 \%$.

To estimate intercolony reproducibility we compare $\delta^{15} \mathrm{~N}$ and $\delta^{13} \mathrm{C}$ records from corals collected from the same location. First, a comparison of two corals (T1101 A12, T1101 A13) collected at $1012 \mathrm{~m}$ from Pioneer Seamount indicates intercolony $\delta^{15} \mathrm{~N}$ and $\delta^{13} \mathrm{C}$ reproducibility of $0.1-1.5$ and $0.1-1.2 \%$, respectively (both typically $<0.5 \%$ ) (Fig. 5a). These corals do not have $\mathrm{D}^{14} \mathrm{C}$-based chronologies, so an assumption of equivalent growth rates is required and may introduce error. Second, by comparing two corals from Monterey Canyon with $\mathrm{D}^{14} \mathrm{C}$ chronologies (T1104 A7, $870 \mathrm{~m}$; T1104 A3, $917 \mathrm{~m}$; Fig. 5b), we refine estimates of intercolony $\delta^{15} \mathrm{~N}$ and $\delta^{13} \mathrm{C}$ reproducibility to $<0.5$ and $<0.4 \%$, respectively. Similarly, Sherwood et al. (2009) found an intercolony reproducibility of $\delta^{15} \mathrm{~N}$ of $\sim 0.5-1.5 \%$ in bamboo corals from Tasmanian seamounts.

While previous research has shown little evidence of diagenesis or reworking of coral organic material (Sherwood et al., 2005), we observe that one specimen (T1102 A3) exhibits anomalous $\delta^{13} \mathrm{C}$ values, with high variability and offsets from the average coral values (Fig. 4) $\left(\delta^{15} \mathrm{~N}\right.$ values do not appear significantly different). While we do not have a complete understanding of why this coral is anomalous, we hypothesize that this specimen may have a superimposed signature due to diagenesis or degradation of the gorgonin. Thus, this coral is not further considered in discussion beyond Fig. 4.

\subsection{1 $\delta^{15} \mathrm{~N}$ composition}

Organic node $\delta^{15} \mathrm{~N}$ (13.9-20.2\%o) shows significant enrichment when compared to surface particulate organic matter $\delta^{15} \mathrm{~N}(3-10 \%$ ), sinking fecal pellets $(2-5 \%$ ), and zooplankton $\delta^{15} \mathrm{~N}(8-15 \%$ ) (Fig. 4) (Saino and Hattori, 1987; Rau et al., 2003; Ohman et al., 2012; El-Sabaawi et al., 2012; Altabet and Small, 1990; Walker and McCarthy, 2012). Along 


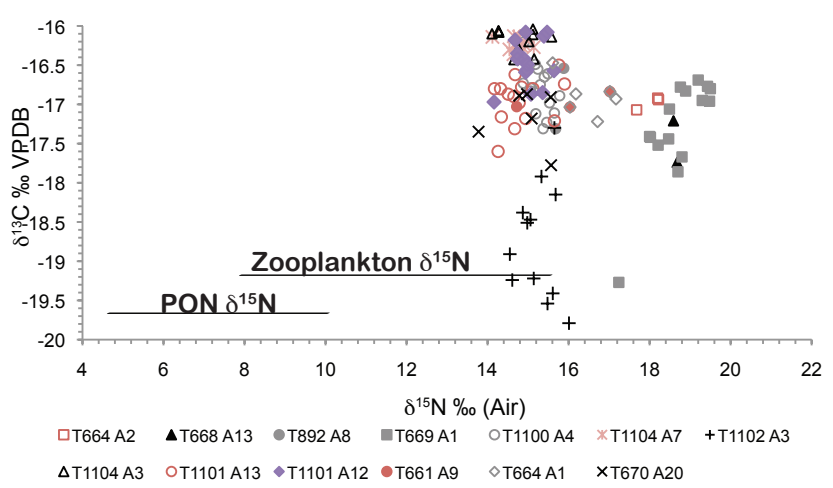

Figure 4. Stable isotopic $\left(\delta^{15} \mathrm{~N}, \delta^{13} \mathrm{C}\right)$ composition for samples from 13 coral specimens. Symbols follow the key, and are the same symbols used in Fig. 2 (live corals: red symbols; dead corals: black or grey symbols). Typical PON and zooplankton $\delta^{15} \mathrm{~N}$ ranges from the California Current are provided for comparison (see text for references); these ranges do not represent typical POM $\delta^{13} \mathrm{C}$ values, which can range from -15 to $-21 \%$ (based upon copepod organic matter from the California Current; Miller et al., 2008).

the California margin, denitrification contributes to the isotopic enrichment of $\mathrm{NO}_{3}^{2-}$, resulting in organic matter $\delta^{15} \mathrm{~N}$ values of $8-10 \%$ o (Altabet et al., 1999). Temporal variability in nitrogen isotopes from sediment trap samples record the upwelling of dentrified $\mathrm{NO}_{3}^{2-}$ from subthermocline waters and incorporation of this signal into phytoplankton (Altabet et al., 1999). We note that $\delta^{15} \mathrm{~N}$ composition of coral gorgonin is more enriched here than in previously documented investigations from elsewhere in the world (Sherwood et al., 2009; Heikoop et al., 2002; Sherwood et al., 2005). Such values are consistent with more enriched baseline $\delta^{15} \mathrm{~N}$ values in phytoplankton due to denitrification, which is then transferred to successive trophic levels.

Field studies indicate that on average the enrichment of bulk $\delta^{15} \mathrm{~N}$ through trophic steps is $\sim 3.0 \%$ o per trophic level (Deniro and Epstein, 1981; Macko et al., 1982; Michener and Schell, 1994). Given their isotopic composition, $\sim 10 \%$ enriched relative to POM and 5\%o enriched relative to zooplankton, these corals appear to feed on sinking zooplankton, marine snow, or deeper water zooplankton species (Fig. 4). Utilizing $\delta^{15} \mathrm{~N}$ and $\delta^{13} \mathrm{C}$ values recorded here together with previously published work (Drazen et al., 2008), we suggest that bamboo corals occupy a similar trophic level to other benthic macrofaunal predators and suspension feeders, such as caridean shrimp, deep-sea fish (macrourids), polychaete worms (Laetmonice sp.), and anemones (B. australis) (Drazen et al., 2008). These findings are also consistent with trophic interpretations from previous DSC studies (Heikoop et al., 2002; Sherwood and Edinger, 2009; Sherwood et al., 2005; Walker and McCarthy, 2012). Samples from coral polyp tissue $(n=8)$ exhibit a similar range of isotopic values $\left(\delta^{15} \mathrm{~N}=6.1\right.$ to $16.4 \%$ ) .
We consider three factors that may influence coral gorgonin $\delta^{15} \mathrm{~N}$ : water depth, distance from shore, and consumption of particles that carry a fractionated $\delta^{15} \mathrm{~N}$ signature associated with denitrification. In contrast to previous DSC investigations (Heikoop et al., 2002) on Primnoa species, we do not find a linear relationship between $\delta^{15} \mathrm{~N}$ and $\delta^{13} \mathrm{C}$ values. Instead, $\delta{ }^{15} \mathrm{~N}$ values cluster around two means: $\sim 15 \%$ and $\sim 18 \%$ o (Fig. 4). These two "clusters" of data are determined by coral habitat depth; all corals exhibiting enriched $\delta^{15} \mathrm{~N}$ values (16.5-18.8\%o) were found below $1954 \mathrm{~m}$ water depth (regression of depth: $\delta^{15} \mathrm{~N}$ yields $R^{2}$ of $0.77, n=12$ ). A broad investigation of suspension and deposit feeders in the Southern Ocean documented a significant depth effect of $\delta^{15} \mathrm{~N}$, such that increased isotopic enrichment is observed with depth (Mintenbeck et al., 2007). This isotopic enrichment is interpreted to reflect the degree of microbial degradation of POM prior to consumption by suspension feeders (Mintenbeck et al., 2007). We interpret the depth-dependent patterns in coral gorgonin $\delta^{15} \mathrm{~N}$ in much the same manner.

During time periods of increased productivity, particles have been shown to sink quickly to the deep ocean with less remineralization and decomposition, likely due to aggregation (Wong et al., 1999). Studies in the Southern California Bight indicate a very short time lag (days) between the onset of upwelling and an observable increase in POC export (Collins et al., 2011). Sinking rates of particles in the North Pacific have been observed from 175 to $300 \mathrm{~m} \mathrm{~d}^{-1}$ (Wong et al., 1999). At $1000 \mathrm{~m}$ water depth, POM fluxes at Station P (North Pacific Gyre) peak in the month of August $\left(\sim 15 \mathrm{mg} \mathrm{m}^{-2} \mathrm{~d}^{-1}\right)$ but maintain fluxes $>2 \mathrm{mg} \mathrm{m}^{-2} \mathrm{~d}^{-1}$ yearround (Wong et al., 1999). Thus, corals in this study may be feeding on particles less than 1 week old during peak productivity periods.

A sediment trap in Monterey Bay (450 m water depth) documented seasonal peaks in mass particle flux, with highest flux in July and lowest in December. Synchronous with these trends in particle flux are variations in the $\delta^{15} \mathrm{~N}$ of sinking POM, with lower $\delta^{15} \mathrm{~N}$ values in summer (7\%o) and enriched (higher) $\delta^{15} \mathrm{~N}$ values in winter $(8.5 \%$ ) (Altabet et al., 1999). Thus, decreased isotopic enrichment is associated with peak flux periods, and is interpreted to reflect better preservation of the particle $\delta^{15} \mathrm{~N}$ (Altabet et al., 1999). In contrast, $\delta^{15} \mathrm{~N}$ enrichment in zooplankton has been linked to food chain elongation, and/or an increase in ${ }^{15} \mathrm{~N}$-rich denitrified waters from the equatorial Pacific (Rau et al., 2003; Ohman et al., 2012). Long-term investigations of zooplankton $\delta^{15} \mathrm{~N}$ in the California Current show an inverse linear relationship between $\delta^{15} \mathrm{~N}_{\text {zooplankton }}$ and average nitrate concentration, where increased $\mathrm{NO}_{3}^{2-}$ is linked to lower $\delta^{15} \mathrm{~N}$ (Ohman et al., 2012). These decadal-scale zooplankton $\delta^{15} \mathrm{~N}$ records show long-term stability, providing evidence for the similarity of trophic position and broadscale productivity through time.

We investigate latitude as a proxy for exposure to denitrified water masses; southernmost coral specimens experience 

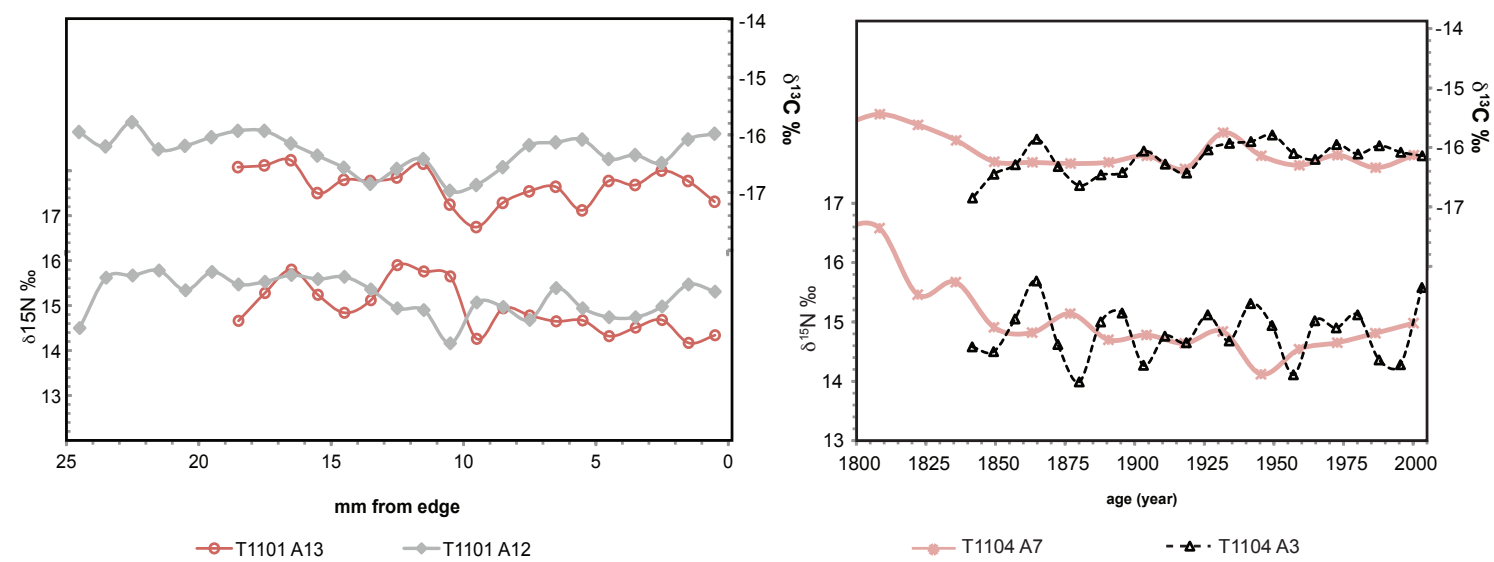

Figure 5. Intercolony isotopic comparison. (A) $\delta^{15} \mathrm{~N}$ and $\delta^{13} \mathrm{C}$ values from two corals from Pioneer Seamount, plotted against sampling location (distance from edge), indicating intercology reproducibility of $<1.5 \%$. These corals do not have $\mathrm{D}^{14} \mathrm{C}$-based chronologies, so an assumption of equivalent growth rates is required and may introduce error in calculating reproducibility. (B) $\delta^{15} \mathrm{~N}$ and $\delta^{13} \mathrm{C}$ values from two corals sampled from the same region (Monterey Canyon). Isotopic values plotted versus age, based upon extension rates established for each coral in Table 3. These data establish reproducibility of $<0.5 \%$ o.

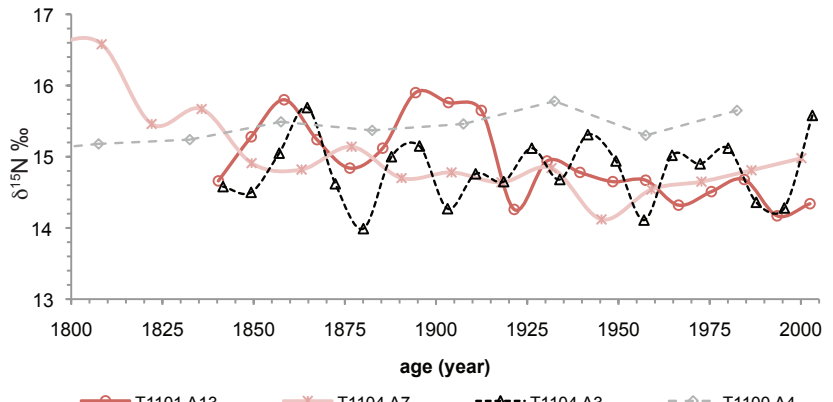

Figure 6. Centennial-length $\delta^{15} \mathrm{~N}$ records from four corals: T1101 A13 (hollow circles, solid line), T1104 A7 (*), T1104 A3 (hollow triangles), and T1100 A4 (hollow circles, dashed line). Age models based upon calculated extension rates in Table 3, and assume a constant extension rate throughout the sampling of the coral. Records show overall stability in $\delta^{15} \mathrm{~N}$ over time.

more influence of eastern tropical North Pacific (ETNP) waters with significant denitrification (Altabet et al., 1999; Liu and Kaplan, 1989; Gruber and Sarmiento, 1997). While denitrification would not directly influence coral gorgonin $\delta^{15} \mathrm{~N}$, this process would fractionate the available nitrate pool that is utilized by the base of the food web. To avoid interpretation of overprinting of the $\delta^{15} \mathrm{~N}$ signal from microbial degradation of particles with depth (discussed above), we utilize only corals from the shallower portions of our study (792$1285 \mathrm{~m}$ ) for this analysis. We find that with the removal of deeper specimens $(>1900 \mathrm{~m})$, there is no significant relationship between coral gorgonin $\delta^{15} \mathrm{~N}$ and latitude (using the average of the outer $15 \mathrm{~mm}$ of gorgonin samples, regressed with latitude). While bamboo corals have the potential to record the denitrification history in this region, this signal appears overprinted by the microbial degradation of particles

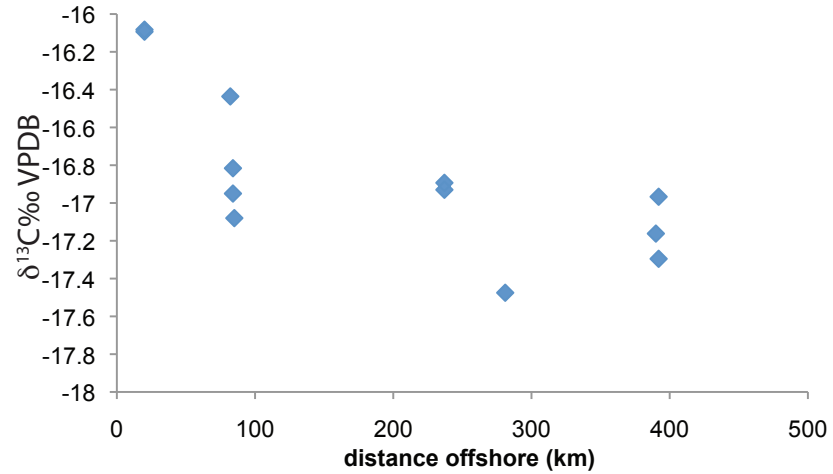

Figure 7. The relationship between $\delta^{13} \mathrm{C}$ of coral gorgonin and distance from shore indicates declining $\delta^{13} \mathrm{C}$ values offshore $(n=12$ coral samples; points represent average values for outer $15 \mathrm{~mm}$ of gorgonin). This relationship has been previously observed in zooplankton and nekton up to $70 \mathrm{~km}$ offshore (Miller et al., 2008).

with depth. Coral gorgonin $\delta^{15} \mathrm{~N}$ does not show a significant relationship with distance from shore, although we do observe higher variability in $\delta^{15} \mathrm{~N}$ values in specimens that are $>200 \mathrm{~km}$ offshore.

Thus, we hypothesize that temporal changes in $\delta^{15} \mathrm{~N}$ of bamboo coral gorgonin primarily reflect surface productivity/carbon export, with increased $\delta^{15} \mathrm{~N}$ reflecting lower productivity. This relationship has been previously proposed in other DSC investigations of Primnoa and bamboo corals (Heikoop et al., 2002; Sherwood et al., 2009). Centenniallength records from T1104 A7 (870 m), T1104 A3 (917 m), T1101 A13 (1012 m), and T1100 A4 $(1285 \mathrm{~m})$ provide evidence for the long-term stability of the $\delta^{15} \mathrm{~N}$ of sinking particles in this region (Fig. 6). These records extend to a centennial scale the previous interpretation of stability in iso- 
topic values, productivity, and trophic relationships in the California Current (Ohman et al., 2012).

\subsection{2 $\delta^{13} \mathrm{C}$ composition}

The carbon isotopic composition of the bamboo coral gorgonin documented here is consistent with marine carbon sources such as those documented from copepod organic matter from the California Current $\left({ }^{13} \mathrm{C}=-15\right.$ to $-21 \%$ ) (Miller et al., 2008). We again consider the same factors when interpreting the $\delta^{13} \mathrm{C}$ results as we did with $\delta^{15} \mathrm{~N}$ : water depth, distance from shore, and latitude as potential controlling factors. We find no significant relationship between water depth or latitude and gorgonin $\delta^{13} \mathrm{C}$. However, we do observe a relationship between distance from shore and $\delta^{13} \mathrm{C}$ (Fig. 7), with declining $\delta^{13} \mathrm{C}$ values occurring offshore. As previously noted, we also observe that anthropogenic bomb spike ${ }^{14} \mathrm{C}$ is only observed in corals $<250 \mathrm{~km}$ from the shoreline, providing further evidence that particle geochemistry, and potentially source, differs between nearshore and offshore regimes.

The observation of an nearshore-offshore difference in $\delta^{13} \mathrm{C}$ composition has been previously noted on smaller spatial scales for both copepods (up to $70 \mathrm{~km}$ offshore) and a variety of other nekton and gelatinous zooplankton (up to $50 \mathrm{~km}$ offshore) (Miller et al., 2008). A variety of mechanisms could contribute to these differences, including isotopic composition and concentration of $\mathrm{CO}_{2}$ (drawdown of $\mathrm{CO}_{2}$ during inshore blooms), species composition and associated differences in growth rates and fractionation, and differing inputs from benthic macrophytes to the food web (e.g., (Miller et al., 2008; Burton and Koch, 1999; Michener and Schell, 1994; Pancost et al., 1997; Fry and Wainright, 1991; Rau et al., 1992). Taken together, this study and previously published literature indicate that POM, copepods, gelatinous zooplankton, nekton, and deep-sea gorgonins all document a decrease in $\delta^{13} \mathrm{C}$ with distance offshore (Miller et al., 2008; Perry et al., 1999; Kline, 1999). This conclusion is also supported by investigations of migratory vs. nonmigratory pinnipeds which document an nearshore-offshore $\delta^{13} \mathrm{C}$ difference (Burton and Koch, 1999). The addition of bamboo coral $\delta^{13} \mathrm{C}$ composition to this nearshore-offshore data set provides strong evidence for benthic-pelagic coupling given the reproducibility of these $\delta^{13} \mathrm{C}$ trends within both planktonic and benthic community members.

\section{Conclusions}

Here we investigate the $\mathrm{D}^{14} \mathrm{C}, \delta^{13} \mathrm{C}$, and $\delta^{15} \mathrm{~N}$ composition of bamboo coral organic node material to understand controls on organic node geochemistry and refine proxies for paleoceanographic use. The presence of the anthropogenic bomb spike in bamboo coral organic node $\mathrm{D}^{14} \mathrm{C}$ confirms that their food source is surface-derived, and allows for de- velopment of gorgonin radial-extension rates based upon $\mathrm{D}^{14} \mathrm{C}$ tie points. $\delta^{15} \mathrm{~N}$ composition provides evidence for a zooplankton-derived food source, with isotopic enrichment in deeper water due to increased particle reworking and fractionation. Centennial-scale $\delta^{15} \mathrm{~N}$ records provide evidence for long-term $\delta^{15} \mathrm{~N}$ stability in the California Current. $\delta^{13} \mathrm{C}$ of coral gorgonin provides evidence for benthic-pelagic coupling in food webs based upon a clear nearshore-offshore $\delta^{13} \mathrm{C}$ gradient.

Acknowledgements. We thank the crew and scientific party of the R/V Western Flyer (Seamounts 2004 and 2007 expeditions) and D. Clague for support of this investigation. Seamount sampling and geochemical analyses were supported by NOAA West Coast Polar Regions Research Program (NA030AR4300104 to T. M. Hill and H. J. Spero) and NSF (OCE 0647872 to T. M. Hill). A portion of this work was performed under the auspices of the U.S. Department of Energy by Lawrence Livermore National Laboratory (contract W-7405-Eng-48 and DE-AC52-07NA27344) including LLNL IGPP funding (H. J. Spero, T. M. Hill, and T. P. Guilderson). Additional support was provided by NA05OAR4310021 (T. P. Guilderson). We appreciate the technical support of the UC Davis Stable Isotope Facility and LLNL CAMS. We appreciate the suggestions of two anonymous reviewers for Biogeosciences Discussions. This is a contribution of Bodega Marine Laboratory.

Edited by: D. Gillikin

\section{References}

Adkins, J. F., Boyle, E. A., Curry, W. B., and Lutringer, A.: Stable isotopes in deep-sea corals and a new mechanism for "vital effects", Geochim. Cosmochim. Ac., 67, 1129-1143, 2003.

Altabet, M. A. and Small, L. F.: Nitrogen isotopic-ratios in fecal pellets produced by marine zooplankton, Geochim. Cosmochim. Ac., 54, 155-163, doi:10.1016/0016-7037(90)90203-w, 1990.

Altabet, M. A., Pilskaln, C., Thunell, R., Pride, C., Sigman, D., Chavez, F., and Francois, R.: The nitrogen isotope biogeochemistry of sinking particles from the margin of the Eastern North Pacific, Deep-Sea Res. Pt. I, 46, 655-679, doi:10.1016/s09670637(98)00084-3, 1999.

Benavides, L. M. and Druffel, E. R. M.: Sclerosponge growth-rate as determined by $\mathrm{Pb}-210$ and Delta-C-14 Chronologies, Coral Reefs, 4, 221-224, doi:10.1007/bf00298080, 1986.

Broecker, W. S., Peng, T. H., Ostlund, G., and Stuiver, M.: The distribution of bomb radiocarbon in the ocean, J. Geophys. Res.Oceans, 90, 6953-6970, doi:10.1029/JC090iC04p06953, 1985.

Burton, R. K. and Koch, P. L.: Isotopic tracking of foraging and long-distance migration in northeastern Pacific pinnipeds, Oecologia, 119, 578-585, 1999.

Chelton, D. B., Bernal, P. A., and McGowan, J. A.: Large-scale internannual physical and biological interaction in the California Current, J. Mar. Res., 40, 1095-1125, 1982.

Collins, L. E., Berelson, W., Hammond, D. E., Knapp, A., Schwartz, R., and Capone, D.: Particle fluxes in San Pedro Basin, California: a four-year record of sedimentation 
and physical forcing, Deep-Sea Res. Pt. I, 58, 898-914, doi:10.1016/j.dsr.2011.06.008, 2011.

Deniro, M. J. and Epstein, S.: Influence of diet on the distribution of nitrogen isotopes in animals, Geochim. Cosmochim. Ac., 45, 341-351, doi:10.1016/0016-7037(81)90244-1, 1981.

Drazen, J. C., Popp, B. N., Choy, C. A., Clemente, T., De Forest, L., and Smith, K. L.: Bypassing the abyssal benthic food web: macrourid diet in the easter North Pacific inferred from stomach content and stable isotopes analyses, Limnol. Oceanogr., 53, 2644-2654, 2008.

Ebert, T. A. and Southon, J. R.: Red sea urchins (Strongylocentrotus franciscanus) can live over 100 years: confirmation with A-bomb (14)carbon, Fish. B.-NOAA, 101, 915-922, 2003.

El-Sabaawi, R. W., Trudel, M., Mackas, D. L., Dower, J. F., and Mazumder, A.: Interannual variability in bottom-up processes in the upstream range of the California Current system: an isotopic approach, Prog. Oceanogr., 106, 16-27, doi:10.1016/j.pocean.2012.06.004, 2012.

Fry, B. and Wainright, S. C.: Diatom sources of ${ }^{13}$ C-rich carbon in marine food webs, Mar. Ecol.-Prog. Ser., 124, 307-312, 1991.

Griffin, S. and Druffel, E. R. M.: Sources of carbon to deep-sea corals, Radiocarbon, 31, 533-543, 1989.

Gruber, N. and Sarmiento, J. L.: Global patterns of marine nitrogen fixation and denitrification, Global Biogeochem. Cy., 11, 235266, 1997.

Heikoop, J. M., Hickmott, D. D., Risk, M. J., Shearer, C. K., and Atudorei, V.: Potential climate signals from the deep-sea gorgonian coral Primnoa resedaeformis, Hydrobiologia, 471, 117124, doi:10.1023/a:1016505421115, 2002.

Hill, T. M., Spero, H. J., Guilderson, T. P., LaVigne, M., Clague, D., Macalello, S., and Jang, N.: Temperature and vital effect controls on bamboo coral (Isididae) isotope geochemistry: a test of the "lines method", Geochem. Geophy. Geosy., 12, Q04008, doi:10.1029/2010GC003443, 2011.

Hill, T. M., LaVigne, M., Spero, H. J., Guilderson, T. P., Gaylord, B., and Clague, D.: Variations in $\mathrm{Sr} / \mathrm{Ca}$ recorded in deep-sea bamboo corals, Paleoceanography, 27, doi:10.1029/2011PA002260, 2012.

Huyer, A.: Coastal upwelling in the California Current system, Prog. Oceanogr., 12, 259-284, 1983.

Ingram, B. L. and Southon, J.: Reservoir ages in eastern Pacific coastal and estuarine waters, Radiocarbon, 38, 573-582, 1996.

Kerr, L. A., Andrews, A. H., Munk, K., Coale, K. H., Frantz, B. R., Cailliet, G. M., and Brown, T. A.: Age validation of quillback rockfish (Sebastes maliger) using bomb radiocarbon, Fishery Bulletin, 103, 97-107, 2005.

Kline, T. C.: Temporal and spatial variability of ${ }^{13} \mathrm{C} /{ }^{12} \mathrm{C}$ and ${ }^{15} \mathrm{~N} /{ }^{14} \mathrm{~N}$ in pelagic biota of Prince William Sound, Alaska, Can. J. Fish. Aquat. Sci., 56, 94-117, 1999.

Largier, J. L., Magnell, B. A., and Winant, C. D.: Subtidal circulation over the Northern California shelf, J. Geophys. Res.-Oceans, 98, 18147-18179, doi:10.1029/93jc01074, 1993.

LaVigne, M., Hill, T. M., Spero, H. J., and Guilderson, T. P.: Bamboo coral $\mathrm{Ba} / \mathrm{Ca}$ : calibration of a new deep ocean refractory nutrient proxy, Earth Planet. Sc. Lett., 312, 506-515, 2011.

Liu, K.-K. and Kaplan, I. R.: The eastern tropical Pacific as a source of $15 \mathrm{~N}$-enriched nitrate in seawater off southern California, Limnol. Oceanogr., 34, 820-830, 1989.
Macko, S. A., Lee, W. Y., and Parker, P. L.: Nitrogen and carbon stable isotope fractionation by two species of marine amphipods: laboratory and field studies, J. Exp. Mar. Biol. Ecol., 63, 145149, 1982.

Manning, M. R., Lowe, D. C., Melhuish, W. H., Sparks, R. J., Wallace, G., Brenninkmeijer, C. A. M., and McGill, R. C.: The use of radiocarbon measurements in atmospheric studies, Radiocarbon, 32, 37-58, 1990.

Michener, R. H. and Schell, D. M.: Stable isotope ratios as tracers in marine aquatic food webs, in: Stable Isotopes in Ecology and Environmental Science, edited by: Lajtha, K. and Michener, R. H., Blackwell, Boston, 138-157, 1994.

Miller, T. W., Brodeur, R. D., and Rau, G. H.: Carbon stable isotopes reveal relative contribution of shelf-slope production to the northern California current pelagic community, Limnol. Oceanogr., 53, 1493-1503, doi:10.4319/lo.2008.53.4.1493, 2008.

Mintenbeck, K., Jacob, U., Knust, R., Arntz, W. E., and Brey, T.: Depth-dependence in stable isotope ratio delta N-15 of benthic POM consumers: the role of particle dynamics and organism trophic guild, Deep-Sea Res. Pt. I, 54, 1015-1023, doi:10.1016/j.dsr.2007.03.005, 2007

Moore, M. D., Schrag, D. P., and Kashgarian, M.: Coral radiocarbon constraints on the source of the Indonesian throughflow, J. Geophys. Res.-Oceans, 102, 12359-12365, doi:10.1029/97jc00590, 1997.

Noe, S. U. and Dullo, W.-C.: Skeletal morphogenesis and growth mode of modern and fossil deep-water isidid gorgonians (Octocorallia) in the West Pacific (New Zealand and Sea of Okhotsk), Coral Reefs, 25, 303-320, 2006.

Nydal, R. and Lovseth, K.: Tracing bomb ${ }^{14} \mathrm{C}$ in the atmosphere 1962-1980, J. Geophys. Res., 88, 3621, 1983.

Ohman, M. D., Rau, G. H., and Hull, P. M.: Multi-decadal variations in stable $\mathrm{N}$ isotopes of California Current zooplankton, Deep-Sea Res. Pt. I, 60, 46-55, doi:10.1016/j.dsr.2011.11.003, 2012.

Pancost, R. D., Freeman, K. H., Wakeham, S. G., and Robertson, C. Y.: Controls on carbon isotope fractionation by diatoms in the Peru upwelling region, Geochim. Cosmochim. Ac., 61, 4983-4991, 1997.

Perry, R. I., Thompson, P. A., Mackas, D. L., Harrison, P. J., and Yelland, D. R.: Stable carbon isotopes as pelagic food web tracers in adjacent shelf and slope regions off British Columbia, Canada, Can. J. Fish. Aquat. Sci., 56, 2477-2486, 1999.

Rau, G. H., Takahashi, T., Des Marais, D. J., Repeta, D. J., and Martin, J. H.: The relationship between $\mathrm{d}^{13} \mathrm{C}$ of organic matter and $\left[\mathrm{CO}_{2}(\mathrm{aq})\right]$ in ocean surface water: Data from a JGOFS site in the northeast Atlantic Ocean and a model, Geochim. Cosmochim. Ac., 56, 1413-1419, 1992.

Rau, G. H., Ohman, M. D., and Pierrot-Bults, A.: Linking nitrogen dynamics to climate variability off central California: a 51 year record based on N-15/N-14 in CalCOFI zooplankton, Deep-Sea Res. Pt. II, 50, 2431-2447, doi:10.1016/s0967-0645(03)00128$0,2003$.

Roark, E. B., Guilderson, T. P., Flood-Page, S., Dunbar, R. B., Ingram, B. L., Fallon, S. J., and McCulloch, M.: Radiocarbon-based ages and growth rates of bamboo corals from the Gulf of Alaska, Geophys. Res. Lett., 32, L04606, doi:10.1029/2004GL021919, 2005.

Robinson, L. F., Adkins, J. F., Keigwin, L. D., Southon, J., Fernandez, D. P., Wang, S.-L., and Scheirer, D. S.: Radiocarbon vari- 
ability in the Western North Atlantic during the last deglaciation, Science, 310, 1469-1473, 2005.

Rosenheim, B. E. and Swart, P. K.: Caribbean sclerosponge radiocarbon measurements re-interpreted in terms of U/Th age models, Nucl. Instrum. Methods, 259, 474-478, doi:10.1016/j.nimb.2007.01.235, 2007.

Saino, T. and Hattori, A.: Geographical variation of the water column distribution of suspended particulate nitrogen and its N-15 natural abundance in the Pacific and its marginal seas, Deep-Sea Res. Pt. I, 34, 807-827, 1987.

Sherwood, O. A., Scott, D. B., Risk, M. J., and Guilderson, T. P.: Radiocarbon evidence for annual growth rings in the deep-sea octocoral Primnoa resedaeformis, Mar. Ecol. Prog. Ser., 301, 129134, doi:10.3354/meps301129, 2005.

Sherwood, O. A. and Edinger, E. N.: Ages and growth rates of some deep-sea gorgonian and antipatharian corals of Newfoundland and Labrador, Can. J. Fish. Aquat. Sci., 66, 142-152, 2009.

Sherwood, O. A., Thresher, R. E., Fallon, S. J., Davies, D. M., and Trull, T. W.: Multi-century time series of ${ }^{15} \mathrm{~N}$ and ${ }^{14} \mathrm{C}$ in bamboo corals from deep Tasmanian seamounts: evidence for stable oceanographirc conditions, Mar. Ecol.-Prog. Ser., 397, 209-218, 2009.

Smith, J. E., Schwarz, H. P., and Risk, M. J.: Paleotemperatures from deep-sea corals: overcoming "vital effects", Palaios, 15, 25-32, 2000.
Strub, P. T., Allen, J. S., Huyer, A., and Smith, R. L.: Large-scale structure of the spring transition in the coastal ocean off Western North-America, J. Geophys. Res.-Oceans, 92, 1527-1544, doi:10.1029/JC092iC02p01527, 1987.

Thresher, R. E., Rintoul, S. R., Koslow, J. A., Weidman, C., Adkins, J. F., and Proctor, C.: Oceanic evidence of climate change in southern Australia over the last three centuries, Geophys. Res. Lett., 31, L07212, doi:10.1029/2003GL018869, 2004.

Tisnerat-Laborde, N., Montagna, P., McCulloch, M., Siani, G., Silenzi, S., and Frank, N.: A high-resolution coral-based $\mathrm{D}^{14} \mathrm{C}$ record of surface water processes in the western Meditterranean Sea, Proceedings of the 2st International Radiocarbon Conference, 55, 1617-1630, 2013.

Walker, B. D. and McCarthy, M. D.: Elemental and isotopic characterization of dissolved and particulate organic matter in a unique California upwelling system: importance of size and composition in the export of labile material., Limnol. Oceanogr., 57, 17571774, 2012.

Wong, C. S., Whitney, F. A., Crawford, D. W., Iseki, K., Matear, R. J., Johnson, W. K., and Page, J. S.: Seasonal and interannual variability in particle fluxes of carbon, nitrogen and silicon from time series of sediment traps at Ocean Station P, 1982-1993: relationship to changes in subarctic primary productivity, Deep-Sea Res. Pt. II, 46, 2735-2760, doi:10.1016/s09670645(99)00082-x, 1999. 